\title{
The Effect of Leadership, Adversity Quotient on Organizational Commitment of PT. Jaya Konstruksi Manggala Pratama Tbk
}

\author{
Sugeng Subagyo ${ }^{1}$, Makruf Akbar², Wibowo ${ }^{2}$ \\ ${ }^{1}$ Graduate Student, State University of Jakarta, Indonesia \\ ${ }^{2}$ State University of Jakarta, Indonesia \\ tambi2015@yahoo.co.uk
}

\begin{abstract}
Purpose: The purpose of this study was to describe and analyze the influence of corporate leadership, adversity quotient on organizational commitment.

Design/methodology/approach: This research used a quantitative approach with survey method. The sample of this research is the whole 204 staff in PT. Jaya Konstruksi Manggala Pratama Tbk is done randomly.

Findings: 1) there is a direct positive influence leadership on organizational commitment; (2) there is a direct positive influence adversity quotient on organizational commitment; (3) there is a direct positive influence to adversity quotient against leadership; (4) there is a indirect positive influence leadership on organizational commitment through adversity quotient

Research limitations/implications: is the whole 204 staff in PT. Jaya Konstruksi Manggala Pratama Tbk.

Practical implications: describing and analyzing the influence of corporate leadership, adversity quotient on organizational commitment.

Paper type: Research paper

Keyword: Adversity quotient, Leadership, Organizational commitment.

\begin{tabular}{|c||c||c||}
\hline Accepted : & Reviewed : & Published : \\
December, 05 2017 & January, 10 2018 & March,30 2018 \\
\hline
\end{tabular}

\section{INTRODUCTION}

One of the major capital needed to expand the task of employees in construction services is a high commitment to the organization. This is related to the nature of work in the construction industry that require accuracy, accuracy, precision, and high speed. Without commitment, precision, accuracy, precision and speed required in the construction industry are difficult to realize. Therefore, the employee organizational commitment is absolutely necessary for the construction company, so its existence from time to time need to be maintained, even improved.

Feels more urgency vitality when the construction company had to compete with other similar companies in the current global era. In fact, in the domestic sphere, the number of construction companies in Indonesia helped to enliven the competition between the construction company, and this leads to the logical consequence of increasing competition to recruit workers, particularly employees as frontline employees, namely dealing directly with customers. Salary offer more promising than competing firms, makes an employee at a construction company may be tempted to bid so that
\end{abstract}

The Effect of Leadership, Adversity Quotient on ...

Sugeng Subagyo, Makruf Akbar, Wibowo 
switching to another construction company. It will be difficult to avoid if the employee has a low organizational commitment. Other than that,

From year to year shows inconsistent data, the findings of the audit are always preceded by a factor of lack of adversity quotient. Any mismatch is always held corrective actions and improvements. This empirical fact to provide proof of lack of awareness of employees who became one of the important aspects of organizational commitment.

The above description shows how vital organizational commitment of employees for the construction company. However, the reality on the ground shows the counterproductive phenomenon that there is still construction company employee who does not have a high organizational commitment. One example is an employee of PT. Jaya Konstruksi Manggala Pratama Tbk which is the object of this study. As a construction services company that is significant in Indonesia, PT. Jaya Konstruksi Manggala Pratama Tbk still have employees who do not fully have a high commitment to the company. The indications include visible in the behavior of poor working professionals in providing services to customers.

The condition is interesting to study scientifically, so that researchers interested in conducting research on organizational commitment of employees of PT. Jaya Konstruksi Manggala Pratama Tbk evaluated from a leadership perspective, adversity quotient, by taking the title: the influence of leadership, and adversity quotient against organizational commitment Employees PT. Jaya Konstruksi Manggala Pratama Tbk.

\section{LITERATURE REVIEW}

\section{Organizational commitment}

Employee organizational commitment are important components that need to be maintained and developed continually, because it is believed a positive impact on the achievement of organizational goals. According Labrague et. al (2018:403) that organizational commitment is broadly defined as an individual employees' strong emotional linkage to the organization. Organizational commitment is basically a form of psychological agreement between the individual and the organization. Commitment is an attitude that is the result of the possibility of identification with the object or result calculative or normative reasons. Furthermore, according to Khunsoonthornkit, and Panjakajornsak (2018:458) that commitment to an organization can be divided into three types: affective, normative, and continuance. This relationship with regard to an organization refers to believing and accepting the organization's aims, values, and effort to acknowledge personnel as representatives of the organization. Organizational commitment can be divided into three types: affective, normative, and sustainable.

Furthermore, according to Min Wu Tso-Jen Chen (2018:77) that A principle of organizational commitment implies that employees make a decision to stay or leave the organization. The principle of organizational commitment implies that the employee made the decision to stay or leave the organization. According Spanuth, and Wald (2017:130) that organizational commitment can be described as an emotional and psychological state that portrays an employee's identification with an organization. Organizational commitment can be described as emotional and psychological state that describes the identification of employees with the organization. Organizational commitment as a state employee identifies himself with a particular organization and objectives and want to maintain membership in the organization.

In line with the above opinion, according to Wombacher, Felfe (2017:9) that organizational commitment is more strongly related to organizational turnover or compliance with organizational rules. Organizational commitment related to the turnover of the organization in accordance with the rules of the organization. Furthermore Hanaysha (2016:289) says that Organizational commitment is very important because when it is built, it would lead to various favourable organizational outcomes. Fostering organizational commitment among employees is very essential, because employees who are highly committed toward their organizations are likely to stay longer, have better performance, and they tend to be highly involved at workplace. The organizational commitment is very important because it can benefit the organization. Fosters organizational commitment of employees is very important, because the employees are very committed to their organizations tend to live longer, have a better performance, and they tend to be engaged in some activity within the organization. Commitment to maintain the interest of employees of the organization, making employees happy to carry out organizational tasks and spend a lot of time in his life with the organizations.

The Effect of Leadership, Adversity Quotient on ... Sugeng Subagyo, Makruf Akbar, Wibowo 
According to Mc Cunn, Kim, Feracor (2018:155) that organizational commitment correlates reliably with employee motivation and satisfaction at work. when conceptualized as three key experiences: (1) acceptance of the values and goals of an organization, (2) willingness to exert effort for an organization, and (3) having a strong desire to remain affiliated with an organization. There are some indicators of organizational commitment including; (1) acceptance of the values and goals of an organization, (2) a willingness to exert effort for the organization, and (3) have a strong desire to remain affiliated with the organization.

Based on the above, it can be synthesized that referred to organizational commitment is a form of employee readiness and desire to devote his efforts to meet the needs of the involvement and active participation in realizing the goals of the organization, with the indicator; (1) sustainability, (2) affective and (3) normative.

\section{Leadership}

Leadership is an issue that is always warm and the subject of interesting discussions, both among academics and practitioners, so that leadership is defined in various ways. In a sense, there are elements or key words for emphasis. According to Zhang, Cao and Wang (2017:2) that leadership, the process of influencing subordinates to facilitate relevant organizational goals attainment, is important in every walk of life. Leadership is the process of influencing subordinates to facilitate the achievement of organizational goals.Furthermore, according to Pilkien, et. al, (2018:914) that leadership competences, which are key for project success.

The leadership competencies are key to the success of the project. Likewise, according to Stiles, Rya, Golightly (2018:3) that leadership as' the process of interaction between leaders and followers, through which leaders could exert their influence on followers to achieve organizational safety goals under the circumstances of organisational and individual factors. The leadership as a process of interaction between leaders and followers, where leaders can exert their influence on followers to achieve organizational goals. The leader and the led must have the same goal. Issues of relationship and influence between the leader and the led.

According Rouine (2018: 2) that defining leadership as an influence process concerned with facilitating the performance of a collective task. Leadership is a position of influence and facilitate collective organizational performance. Leadership in accordance with his individual perspective and the most interesting aspects of the symptoms of attention, after a review of the literature of leadership depth. Further, according to Ul-Haq, and Anwar (2018:180) that leadership is an interpersonal relationship in which power and influence is unevenly distributed and one person directs and controls the behaviors of others.

Leadership is a relationship in which power and influence are distributed evenly and the person directing and controlling the behavior of others. Meanwhile, according to Madanchian Mitra et. al (2018:969) that ethical leadership the demonstration of normatively appropriate conduct through personal actions and interpersonal relationships, and the promotion of such conduct to followers through two-way communication, reinforcement, and decision-making. Demonstrate leadership normative behavior through personal action and improve interpersonal relationships, as well as the promotion of behavior of followers in two ways, namely by strengthening communication and decision making.

According Ferkins, Shilbury, and Boyle (2017:2) that leadership is that leadership does not necessarily reside within one person; instead, it is a concept that can be shared, distributed, and indeed generated collectively. Leadership is leadership not always be in one person; Instead, leadership is a concept that can be shared, distributed, and produced collectively. According to Miao Yu, et al (2018:1) that leadership is a 3-stage process, wherein the project manager takes justification perception and demand factors as essential conditions for his/her empowerment orientation, which in turn frames the announcement, acceptance, control, autonomy and future of horizontal leaders. The leadership has a 3 -stage process, in which the manager has the orientation of empowerment, control, and has a vision of the future.

Leaders use of formal authority for organizing, directing, controlling the subordinate responsible, so that all parts work is coordinated in order to achieve company goals. Leaders must first be a able to grow and develop all the best in subordinates. Simply a good leader is the one who helped develop others, so that eventually they no longer require its leaders. According to Scott, (2018:8) that an early review of the literature leadership in formal roles noted four essential dimensions of leadership. The dimensions encompassed the concepts of process, influence,

The Effect of Leadership, Adversity Quotient on ... Sugeng Subagyo, Makruf Akbar, Wibowo 
group setting or context, and vision. The leadership has a very important fourth dimension include: process, influence, control, and vision.

Based on a review of the definition of leadership as has been described, it can be synthesized that is the leadership is a skill in influencing, motivating and enabling behavior of others/subordinates/followers to contribute to the achievement of organizational goals with indicator (1) create a vision, (2) influence , (3) direct, (4) motivation, (5) inspires, and (6) protect subordinates.

\section{Adversity quotient}

Everyone basically harbored a desire to achieve success in the broadest sense. Persistence to achieve success is what the Stoltz (2006:92) Self-referred or Adversity Adversity Quetient, namely persistence in overcoming all obstacles in order to climb the ladder of success desired. Furthermore, according to Singh, Sharma (2017:86) that the science of resilience or the adversity quotient (AQ) is a measure of the cap ability of an individual in facing the difficult situations in life. Adversity quotient is a measure of the ability of individuals in the face of difficult situations in life. Meanwhile, according to Tian, and Fan (2014:252) that who conceptualized the adversity quotient as an index of how well an individual may respond when misfortune occurs. Individuals with a high adversity quotient are better able to cope with setbacks and choose constructive responses that turn obstacles into opportunities. In short, the adversity quotient (AQ) indexes how well a person can withstand adversity and his/her ability to surmount it.

Adversity quotient as an index of how each individual is able to respond when something goes wrong. Adversity quotient able to overcome obstacles and problems and be able to think of solutions. In short, adversity quotient is an index of how well a person can endure the pain and the ability to solve any problems.

The term misery or misfortune described in the large dictionary Indonesian as suffering or distress, Language Center, 2005). Nelson (2017:1) defines it as a measure of a person's ability to overcome misfortune. According to Ahmad (2013:55) that adversity quotient how a person has high durability, hardiness to face difficulties, obstacles, will not repeat the error, and will accept responsibility for the problems. In the run of his life, a person often make plans that will do or objectives to be achieved. In fact, every human life is not uncommon passed out of the plan in the form of scenarios. Not a few people were disappointed, frustrated, and even depression if it gets difficult to fulfill the expectations built, but not a few who made it through. Skills past obstacles and turn them into opportunities is called adversity quotient.

Based on the previous description, it can be synthesized that adversity quotient means anticipation of the individual against adversity and hardship it faces and turn them into opportunities for success indicators: (1) control difficulties; (2) the ability to find solutions; (3) The power of adversity.

\section{METHOD}

This study used survey method with descriptive quantitative approach based on the results of testing the theory of the variables and perform statistical data analysis procedures (analysis track / path analysis). With the purposes and research problems, this research is explanatory (explanatory research), which seeks to explain the causal relationship (causality relationship) between the variables: leadership and adversity quotient against organizational commitment. Affordable target population is all employees at PT. Jaya Konstruksi Manggala Pratama Tbk amounted to 418 employees. The number of research subjects sampled in this study is as much as 204 employees.

Constellation studies to determine the influence of variables can be plotted on the chart below are as follows;

The Effect of Leadership, Adversity Quotient on ... Sugeng Subagyo, Makruf Akbar, Wibowo 


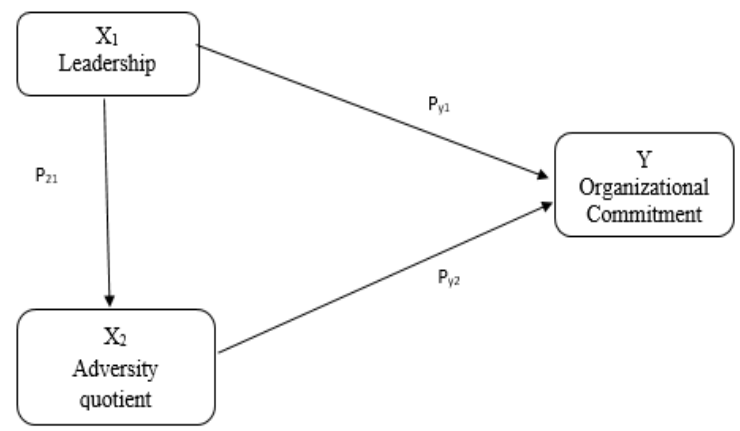

Information :

Figure 1 Model Constellation Problems

Y : Organizational Commitment

$\mathrm{X}_{1} \quad$ : Leadership

$\mathrm{X}_{2} \quad$ : Adversity quotient

From Figure 1 above, organizational commitment $(\mathrm{Y})$ is the dependent variable. leadership $\left(\mathrm{X}_{1}\right)$, And Adversity quotient (An independent variable. Constellation influence illustrates that leadership $\mathrm{X}_{2}$ ), adversity quotient is the independent variable that has an influence on organizational commitment $(\mathrm{Y})$.

\section{RESULT AND DISCUSSION}

The results obtained after analyzing the model used as the basis for answering hypotheses and draw conclusions in this study. The explanation for the answer hypothesis can be described as follows:

\section{Direct Influence of Positive Leadership (X1) to organizational commitment (Y)}

Results of the analysis of the first hypothesis resulted in the finding that the leadership of a positive direct effect on organizational commitment. From the data results of calculations for modeling regression equation between organizational commitment to leadership. Thus the relationship model of simple regression equation is $\mathrm{Y}=76.481+$ $0,375 \mathrm{X} 1$. Prior to the regression equation model further analyzed and used in drawing conclusions, first tested the significance and linearity regression equation.

Based on testing, the value of signing 0.141. Sign value (0.141)>0.05, this means that the linear distribution of organizational commitment to leadership. Based on these findings we can conclude that organizational commitment is directly affected positively by the leadership. Increased leadership will lead to increased organizational commitment. The demands of an employee's commitment indicates the level of completion of work and quality of work that lead to the creation of efficiency and effectiveness in completing the work so that it can increase organizational commitment of employees.

According to Steffens, et. al (2018:1) that how Feedback About Leadership Potential Impacts Ambition, Organizational Commitment, and Performance. An employee who has good feedback, and ambition, it has the potential leaders of the future and can affect organizational commitment. Meanwhile, according Einolander (2015:668) that company managers and leaders often have to operate with incomplete information when making decisions regarding their employees. To make effective decisions, information regarding the employees' commitment organizational and engagement in their work is highly valuable for management.

The Effect of Leadership, Adversity Quotient on ...

Sugeng Subagyo, Makruf Akbar, Wibowo 
The company's managers and leaders often get incorrect information when making decisions about their employees so that the lower level of organizational commitment of employees. While leaders make effective decisions, accuracy of information, then the leadership can increase employee commitment.

PT NKE tbk as certainly interested organizations to build the capacity of employees who have a high commitment to the organization. With this commitment the organization will be easier to organize themselves and manage organizational tasks, especially in implementing education and training according to the needs of the organization. The leader's role in building this commitment is very crucial and important because of the leadership that is more aspirational, ie listen to the aspirations of employees, and leadership transformational, that are able to influence and instill positive values in subordinates, then there will be able to increase employee commitment to the organization PT NKE tbk.

\section{Direct Impact Positive Adversity quotient (X2) on organizational commitment (Y)}

The results of the analysis of the second hypothesis resulted in the finding that adversity quotient positive direct effect on organizational commitment. From the data results of calculations for modeling regression equation between organizational commitment with adversity quotient. Thus the relationship model of simple regression equation is $\mathrm{Y}=$ $92.839+0,264 \mathrm{X} 2$. Prior to the regression equation model further analyzed and used in drawing conclusions, first tested the significance and linearity regression equation.

Based on testing, the value of signed 0,388 . Sign value $(0,388)>0.05$, this means that the organizational commitment towards adversity quotient linear distribution. Based on these findings we can conclude that organizational commitment is directly affected positively by adversity quotient. Increased adversity quotient will lead to increased organizational commitment.

According Somaratne, Jayawardena and Perera (2017:46) that adversity quotient has proved to improve performance levels, leadership styles and practices, resilience, promotions, retention, optimism and commitment to change. Adversity quotient been proven to increase the level of performance, style and practice leadership, resilience, promotion, retention, optimism and organizational commitment. The ease and hardship is a reality of life that must have faced. As a human being, is obliged to do the best we can, to search the streets of ease and avoid the doors difficulty. It is necessary to understand the factors that give rise to difficulties. It is very important in order to address the difficulties according to the situation and condition.

The ease and hardship is a reality of life that must have faced. As a human being, is obliged to do the best we can, to search the streets of ease and avoid the doors difficulty. It is necessary to understand the factors that give rise to difficulties. It is very important in order to address the difficulties according to the situation and condition.

\section{Direct Influence of Positive Leadership (X1) to Adversity quotient (X2)}

The results of the sixth hypothesis analysis provides findings that the leadership of a positive direct effect on adversity quotient. From the data results of calculations for the preparation regression model between leadership with adversity quotient. Thus, the relationship model of simple regression equation is $\mathrm{X} 2=86.775+0,226 \mathrm{X} 1$. Prior to the regression equation model further analyzed and used in drawing conclusions, first tested the significance and linearity regression equation.

Based on testing, the value of signing 0.565. Sign value (0.565)> 0.05, this means against the leadership Ketehanmalangan linear distribution. Based on these findings we can conclude that adversity quotient directly influenced positively by the leadership. Increased leadership will lead to increased adversity quotient.

Based on these findings we can conclude that adversity quotient directly influenced positively by the leadership. Increased leadership will lead to increased adversity quotient. According to Tian, and Fan (2014:252) that who conceptualized the adversity quotient as an index of how well an individual may respond when misfortune occurs. Individuals with a high adversity quotient are better able to cope with setbacks and choose constructive responses that turn obstacles into opportunities. In short, the adversity quotient (AQ) indexes how well a person can withstand adversity and his/her ability to surmount it.

Adversity quotient as an index of how each individual is able to respond when something goes wrong. Adversity quotient able to overcome obstacles and problems and be able to think of solutions. In short, adversity quotient is an index of how well a person can endure the pain and the ability to solve any problems.

The Effect of Leadership, Adversity Quotient on ... Sugeng Subagyo, Makruf Akbar, Wibowo 


\section{Indirect Influence Positive Leadership (X1) to organizational commitment (Y) through Adversity quotient (X2)}

The indirect effect of leadership on organizational commitment through leadership is the product of three coefficients channels, namely: leadership path coefficient against adversity quotient ( $\beta 21)$, adversity quotient against organizational commitment ( $\beta \mathrm{y} 2)$. Large indirect effect of leadership on organizational commitment through adversity quotient by: $(0.263)(0.173)=0.045$. In order to get the total effect of leadership on organizational commitment amounted to $0.333+0.045=0.378$ through adversity quotient.

Organizational commitment as one's attitude to the organizations linked with the organization's identity by indicators continuant commitment, normative commitment and affective commitment. Commitment of employees in the organization is very important in building a strong and solid organization where employees are very attached to the organizations that make the organization as a part of life.

According to Acar (2012:217) that based on empirical evidences in the literature, leadership is an important component in the organizational commitment process, as well. Moreover, leadership is crucial for the organizational effectiveness, and the development and the changes of organizational culture. Whether the literature abounds of evidences about the positive effects of both leadership styles and organizational culture on organizational commitment. Based on empirical evidence in the literature, leadership is an essential component in the process of organizational commitment. In addition, leadership is an important part in organizational effectiveness, leadership can increase organizational commitment and positive impact on organizational culture.

\section{CONCLUSION}

This study is intended to look for factors that may affect the organizational commitment of employees of PT. Jaya Konstruksi Manggala Pratama Tbk including leadership, adversity quotient. Based on the results of statistical hypothesis testing and discussion, the research resulted in the following:

1. Leadership positive direct effect on organizational commitment of employees of PT. Jaya Konstruksi Manggala Pratama Tbk. It shows if the leadership is executed properly it will lead to increased organizational commitment.

2. Adversity quotient positive direct effect on organizational commitment of employees of PT. Jaya Konstruksi Manggala Pratama Tbk. This shows if adversity quotient executed properly it will lead to increased organizational commitment.

3. Leadership positive direct effect on adversity quotient employees of PT. Jaya Konstruksi Manggala Pratama Tbk. It shows if the leadership is executed properly it will lead to increased adversity quotient.

4. Leadership positive indirect effect on organizational commitment of employees of PT. Jaya Konstruksi Manggala Pratama Tbk. It was concluded that adversity quotient may mediate the effect of leadership on organizational commitment. This is to be able to increase the organizational commitment of leadership increases adversity quotient prior improve organizational commitment.

\section{Recommendation}

Based on empirical findings obtained from this study, researchers express some suggestions for leadership influence, adversity quotient, on the organizational commitment of employees of PT. Jaya Konstruksi Manggala Pratama Tbk, as follows.

1. Leadership conditions should be improved because it proved positive direct effect on organizational commitment of employees of PT. Jaya Konstruksi Manggala Pratama Tbk. The weakest aspect of leadership is nurturing subordinates. For that leaders can protect the main subordinate employees so as to improve their organizational commitment to PT. Jaya Konstruksi Manggala Pratama Tbk.

2. Adversity quotient conditions should be improved because it proved positive direct effect on organizational commitment of employees of PT. Jaya Konstruksi Manggala Pratama Tbk. Adversity quotient the weakest aspect is the power of adversity. For that employees need to possess power of adversity.

The weakest aspect of the organizational commitment of employees of PT. Jaya Konstruksi Manggala Pratama Tbk is normative. Normative can be driven by employees is expected to increase organizational commitment. .

The Effect of Leadership, Adversity Quotient on ... Sugeng Subagyo, Makruf Akbar, Wibowo 


\section{REFERENCES}

Acar, A. Zafer. (2012). Organizational Culture, Leadership Styles and Organizational Commitment in Turkish logistics industry. Procedia - Social and Behavioral Sciences.

Ahmad, Syarwani. (2013). Adversity quotient Leadership Kepala Sekolah. Yogyakarta: Pustaka Felicha.

Einolander, Jarno. (2015). Evaluating Organizational Commitment In Support Of Organizational Leadership. Procedia Manufacturing.

Ferkins, Lesley, David Shilbury, Lan O Boyle. (2017). Leadership in Governance: Exploring Collective Board Leadership In Sport Governance Systems. Sport Management Review.

Hanaysha, Jalal. (2016). Testing the Effects of Employee Engagement, Work Environment, and Organizational Learning on Organizational Commitment. Procedia - Social and Behavioral Sciences.

Khunsoonthornkit, Ardharn, Vinai Panjakajornsak. (2018). Structural Equation Model to Assess The Impact of Learning Organization and Commitment on The Performance of Research Organizations. Kasetsart Journal of Social Sciences.

Labrague, Leodoro J. et. al. (2018). Organizational Commitment And Turnover Intention Among Rural Nurses in the Philippines: Implications for Nursing Management. International Journal of Nursing Sciences.

Madanchian, Mitra, et. al. (2018). The Impact Of Ethical Leadership On Leadership Effectiveness Among SMEs in Malaysia. Procedia Manufacturing.

Mc Cunn, Lindsay J. Amy Kim, James Feracor. (2018). Reflections on a Retrofit: Organizational Commitment, Perceived Productivity and Controllability In a Building Lighting Project In The United States. Energy Research $\&$ Social Science.

Nelson, Davis. (2015). Moral Magazine, (http://spiraldynamic.com/magazine/editorial/ark.htm).

Pilkien, Margarita, et. al. (2018). The Governance of Horizontal Leadership In Projects. International Journal of Project Management.

Pusat Bahasa Departemen Pendidikan Nasional. (2005). Kamus Besar Bahasa Indonesia, Edisi Ketiga (jJakarta: Balai Pustaka.

Rouine, Ibtissem. (2018). Target Country's Leadership Style and Bidders' Takeover Decisions. International Review of Financial Analysis.

Scott, Elaine S. (2018). A New Leadership Development Model for Nursing Education. Journal of Professional Nursing.

Singh, Sandeep, Tanu Sharma. (2017). Affect of Adversity Quotient on the Occupational Stress of IT Managers in India. Procedia Computer Science.

Somaratne, Jayawardena and Perera. (2017). Impact of Adversity Quotient on Stress Levels of Middle-Level Managers of Non-Governmental Organisation (NGO) Sector. Tropical Agricultural Research.

Spanuth, Thomas, Andreas Wald. (2017). Understanding the Antecedents of Organizational Commitment in The Context of Temporary Organizations: An empirical study. Scandinavian Journal of Management.

Steffens, Niklas K. et. al. (2018). How Feedback About Leadership Potential Impacts Ambition, Organizational Commitment, and Performance. The Leadership Quarterly.

Stiles, Shelley, Brendan Rya, David Golightly. (2018). Evaluating Attitudes To Safety Leadership Within Rail Construction Projects. Safety Science.

Stoltz, Paul G. (b). (2006). Adversity Quotient a Work, terjemahan Alexander Sindoro. Batam: Interaksara.

Tian, Yan, Xiuzhen Fan. (2014). Adversity Quotients, Environmental Variables and Career Adaptability in Student Nurses. Journal of Vocational Behavior.

Tso-Jen Chen, Chi-Min Wu. (2018). Collective Psychological Capital: Linking Shared Leadership, Organizational Commitment, and Creativity. International Journal of Hospitality Management.

Ul-Haq, Muhammad Asrar, Sadia Anwar. (2018). The Many Faces of Leadership: Proposing Research Agenda Through a Review of Literature. Future Business Journal.

Wombacher, Jörg Christian, Jörg Felfe. (2017). Dual Commitment in the Organization: Effects of the Interplay of Team and Organizational Commitment on Employee Citizenship Behavior, Efficacy Beliefs, and Turnover Intentions. Journal of Vocational Behavior.

The Effect of Leadership, Adversity Quotient on ...

Sugeng Subagyo, Makruf Akbar, Wibowo 
Yu, Miao, et. al. (2018). Empowerment: The Key to Horizontal Leadership In Projects. International Journal of Project Management.

Zhang, Lianying, Tingting Cao, and Yu Wang. (2017). The Mediation Role of Leadership Styles In Integrated Project Collaboration: An Emotional Intelligence Perspective. International Journal of Project Management. 